\title{
SUMMER TANAGER \\ AT DAUPHIN, MANITOBA
}

WILLIAM J. WALLEY, 222 Bossons Avenue, Dauphin, Manitoba. R7N OR2

Manitoba records of the Summer Tanager were summarized by Jim Purdy when he reported an adult male near Russell, the eighth documented individual for the province. ${ }^{2}$ This report documents another Manitoba record.

Failing to see or hear the tanager near Russell 3 April 1986 (not 13 April as reported ${ }^{2}$ ), my chances of ever recording one seemed slim. The scenario in which I was to see my first was most improbable. At noon 15 May 1990, while having lunch in the Dauphin Regional Comprehensive Secondary School staff dining room, a student, Bob Kostuchuk, delivered a Summer Tanager to me at my table. We took it to the Biology Room and put it in a small bird cage. The bird thrashed about wildly, then settled down and quickly took and swallowed several mealworms offered to it. Kostuchuk said that it had been on the grass on the north side of the school and had flown up onto his shoulder, then onto a companion whereupon he caught it by hand. The bird was a first year male (see photo).

Field guides consulted ensured that the tanager was not a Hepatic Tanager, a similar species which also nests in the southern United States but not in Canada. Following is the description of the bird: length about $17 \mathrm{~cm}$; head and breast red with an orange tinge; nape a mottling of olive through the red-orange; tail, outer feathers gray-brown edged with yellow, middle feathers gray; undertail coverts bright yellow; upperwing brown with olive edges; underwing gray with yellow near the body; beak, which was large for the size of the bird, gray with light yellowish edges; legs gray.

Several local birders observed and photographed the tanager in the Biology Room and a brief writeup and photograph appeared in the local paper. On 16 May, the tanager readily consumed mealworms and the following day ate several earthworms, including a nightcrawler. When released from the cage in the room, the bird flew normally and perched on the outstretched wing of a mounted Saw-whet Owl and then on the crown of a mounted White Pelican. Its apparent strength in making short flights suggested that it was ready to be returned to the wild.

An aluminum band (1501 38 292) had been placed on its left leg 16 May and the bird was released just north of Riding Mountain National Park, southeast of Dauphin, on the evening of 17 May. It flew to the top of a tall aspen, then launched off to the southwest and was lost from view by obstructing trees. When located three minutes later it was standing on a worked field about 150 $m$ from where it took off. I approached the bird on foot and, when I was $30 \mathrm{~m}$ from it, it flew powerfully for $60 \mathrm{~m}$ and perched on the top of a Bur Oak. From there it flew $100 \mathrm{~m}$ south and landed again on the field. 
The tanager made several short flights of 5 to 20 m before it flew from the field and disappeared into an aspen bluff where it sang. It was not seen again.

It is unknown whether the bird had a minor injury or was exhausted just prior to its capture by Kostuchuk. Surely it was in better condition when released two days later. However, its tendency to land on the ground without apparent foraging behaviour seemed peculiar.

Summer Tanagers winter mainly from Mexico to Bolivia and breed as far north as southern Missouri. The species has a reputation for overshooting its breeding range in the spring." This would be especially true of inexperienced first-year birds making their initial northern migration as was the case with this bird.

I thank Bob Kostuchuk for his thoughtfulness in bringing the Summer Tanager to me.

1. FARAND, JOHN JR. 1983. The Audubon Society master guide to birding. Vol. 3 Old World warblers to sparrows. Alfred A. Knopf, New York. $399 \mathrm{pp}$.

2. PURDY, JIM. 1986. A Summer Tanager in Manitoba. Blue Jay 44:184186.

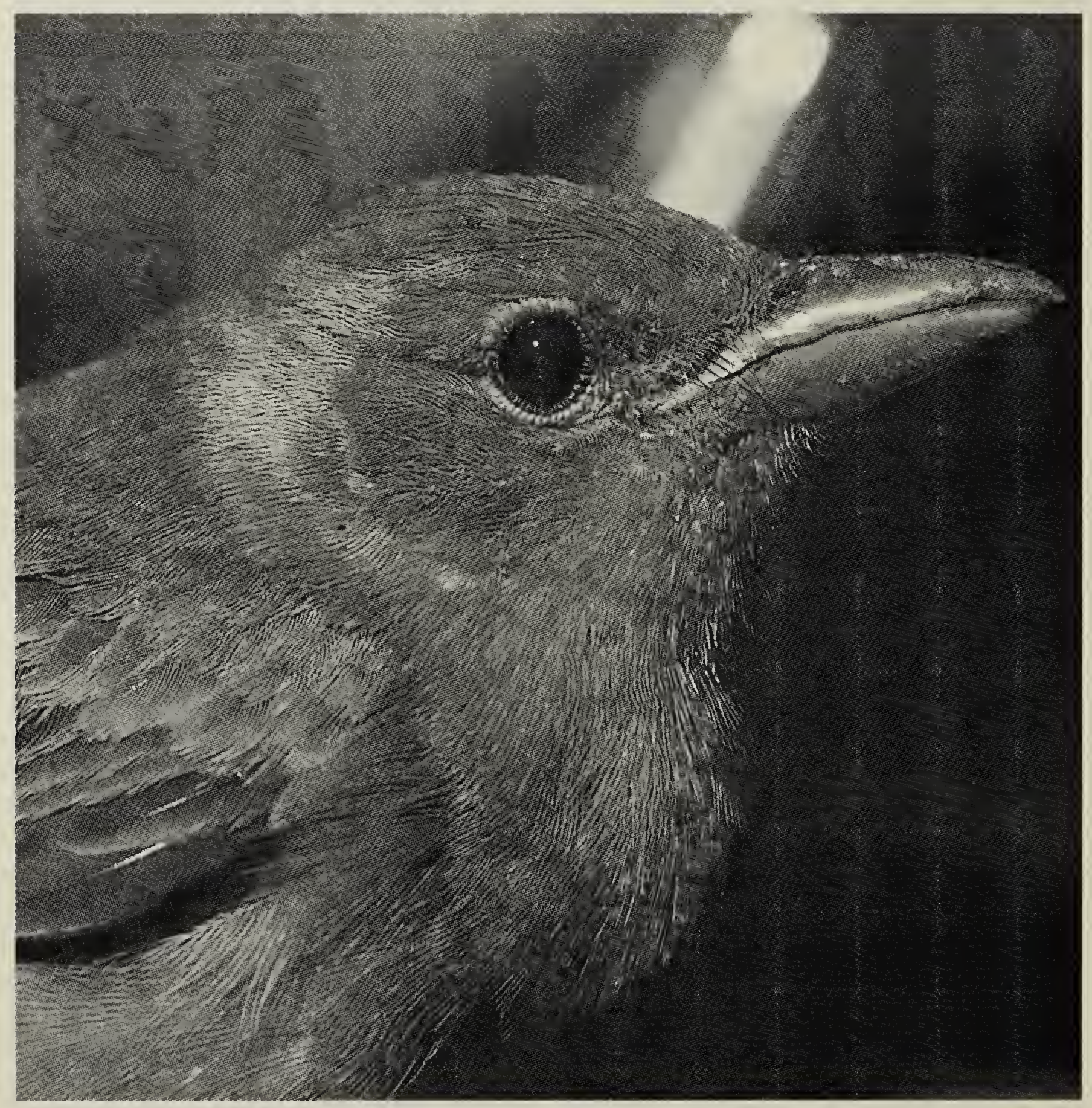

Summer Tanager, Dauphin, Manitoba, May 1990. William J. Walley 